\title{
Maria Lang - Idyll och ideologi
}

\author{
Av Ulf Carlsson
}

Maria Langs ställning inom svensk kriminallitteratur är långt ifrån oomstridd. Det har hänt att hon blivit raskt avfärdad, med K. Arne Bloms ord betecknad som en "ointressant hybrid av Agatha Christie och Mary Roberts Rinehart"'. Framförallt kvinnliga röster har samtidigt höjts till hennes försvar och senast har Sara Kärrholm ägnat Lang ett kapitel i avhandlingen Konsten att lägga pussel. Deckaren och besvärjandet av ondskan i folkhemmet, 2005. Vad man borde kunna enas om är att Lang från debuten 1949 lyckades skapa sig en egen nisch inom en genre som i allt högre grad splittrats av djupt skiljaktiga varianter. I kontrast inte bara till maskulint präglade s.k. hårdkokta deckare, utan också till majoriteten engelskspråkiga pusseldeckare, använde hon sig av en kvinnlig berättare, Puck Bure, i de åtta första romaner som här är aktuella: Mördaren ljuger inte ensam, 1949, Farligt att förtära, 1950, Inte flera mord, 1951, En skugga blott, 1952, Rosor, kyssar och döden, 1953, Tragedi på en lantkyrkogård, 1954, Se döden på dig väntar, 1955, och Mörkögda augustinatt, 1956. Som doktorand i litteraturhistoria kunde Puck ge kriminalromanen den kulturella polityr som utmärkte sådana akademiskt anknutna företrädare som Dorothy L. Sayers, Edmund Crispin och Michael Innes. Samtidigt försåg hon genren med en dos romantik i modern tappning, genom sin öppenhjärtiga hållning till de egna kärleksfröjderna med maken Einar, men också genom att mordhistorierna gärna kretsade kring passioner och relationskonflikter av våldsam art.

Med fokus på Tragedi på en lantkyrkogård diskuterar jag i det följande Langs relationer till genretraditionen, främst pusseldeckaren och efterkrigstidens psykologiska kriminalroman, och till melodramat. Men framförallt koncentreras artikeln på tre aspekter av betydelse för Maria Langs författarskap. "Idyllen" beskriver hur Lang utnyttjar detta för hennes romaner centrala motiv. "Kvinnliga positioner" behandlar hur kriminalromanen hos Lang korsas med inslag av populärromantiska mönster. "Ideologin" försöker utreda hur hennes texter kretsar kring föreställningar om en bred och konfliktfri samhällelig gemenskap, i samklang med 50-talets dominerande ideologiska tendenser.

Tragedi på en lantkyrkogård från 1954 är på många sätt representativ för författaren, men skiljer sig från de av hennes romaner som ligger närmare pusseldeckarens exklusiva inriktning på samhällets övre skikt. Mordet på en lanthandlare och senare även hans hustru liksom den bakgrund till brottet som till sist blir klarlagd ger istället en anstrykning av vardaglig realism, om än bruten genom det borgerligt akademiska perspektiv som är Puck Bures. Här saknas också de drag av psykisk avvikelse hos mördaren som förekommer i

1 K. Arne Blom, ”Appendix”, i Julian Symons, Lilla mordboken. Från detektivhistoria till kriminalroman, Berghs 1979, s. 313. Mary Roberts Rinehart är känd - och vanligtvis nedskriven - för en lång rad romaner, där kvinnliga hjältinnor försätts, eller försätter sig själva, i skräckladdade situationer. Mest framgångsrik var hennes The Circular Staircase, 1908 ( Spiraltrappan i flera svenska upplagor ). 
några andra Lang-deckare och som kritikerna ibland reagerat mot. Redan 1962 lyfte den annars relativt kritiske Åke Runnquist fram just Tragedi... i Langs produktion och beskrev den, dock utan närmare motivering, som "elegant neddämpad"2.

Berättelsen sådan som vi möter den ser ut som följer. Kyrkoherden Tord Ekstedt, änkeman med elvaårig dotter, Lotta, har som gäster över julhelgen brorsdottern Puck Bure, hennes man historiedocenten Einar, och hennes far, professorn Johannes Ekstedt. I prästgården finns också en husföreståndarinna, den medelålders ogifta Hjördis Holm. På julaftons kväll begär grannfrun, den vackra Barbara Sandell, hjälp att leta efter sin försvunne man, lanthandlaren Arne Sandell, som Puck senare påträffar mördad i hans butik. Snart anländer paret Bures gemensamme vän Christer Wijk, chef för riksmordkommissionen, för att leda utredningen. Till de misstänkta hör Sandells anställde, den halvt försupne Connie Lundgren, som burit agg gentemot Arne då de en gång konkurrerat om att överta lanthandeln. Dit hör också Tekla Motander, "änkedisponentska", som möjligen velat dölja sitt ansvar för sin makes död ett antal år tidigare. Nära brottsplatsen har dessutom befunnit sig den unge Mårten Gustafsson, vars utmanande attityd och kommunistiska sympatier gör honom suspekt hos flertalet ortsbor. Av en tillfällighet kommer änkan Barbara sanningen på spåren, men blir det andra offret. I kamp med mördaren men snarast genom olyckshändelse störtar hon ner i Arnes ännu öppna grav. I en dramatisk finalscen avslöjas och grips till sist Hjördis Holm. Hon är då i färd med att på ett eller annat sätt försöka tysta den lilla Lotta, vars förmåga att snappa upp information gjort henne till ett farligt vittne.

Det visar sig att Hjördis under sin uppväxt levt isolerad med sin tyranniske far på en avlägsen gård i Jämtland. Under krigsåren möter hon den inkallade Arne Sandell och upplever då sin första och enda kärlekshistoria. När Arne efter kriget får möjlighet att köpa en lanthandel, lånar han 50.000 kronor av Hjördis, som efter faderns död funnit dessa pengar undangömda. Hjördis lever i tron att paret skall gifta sig, men Arne ingår istället äktenskap med Barbara. Flera år senare flyttar Hjördis till den by där Arne har sin lanthandel och får anställning i prästgården. Hon hemlighåller sin gamla relation med Arne men kräver nu av honom att han skall betala tillbaka sitt lån. På julaftons eftermiddag utbryter ett gräl mellan dem på lanthandelns kontor och sedan Arne slagit Hjördis dödar hon honom med en yxa.

Berättaren Puck Bure är liksom Trenters Harry Friberg på en gång en biträdande Watson-figur, här i förhållande till Christer Wijk, och romanernas egentliga huvudperson, nära knuten till skeendet och framförallt starkt emotionellt engagerad. Maria Lang skriver i sin självbiografi att hon med tiden blev "grundligt trött" på Puck därför att "alla tankar och spekulationer måste silas genom hennes omdöme". ${ }^{3}$ Samtidigt som Puck Bure bidrar till Langs egenart - hennes romaner med en opersonlig berättare från slutet av 50-talet framstår som mera konventionella - tenderar berättarrösten utan tvekan att bli överdrivet känslomättad. Man kan konstatera att just i Tragedi... är Puck något sparsammare än annars med sin entusiasm över umgängets trivsamhet, Den Stora Konstens skönhetsupplevelser och möjligheten att betygsätta kvinnliga garderober. Inte desto mindre tillåts hon notera hur "utsökt"

2 Jörgen Elgström, Tage LaCour, Åke Runnquist, Mord i biblioteket. Detektivromanens märkvärdiga historia, Bonniers 1961, s. 198.

3 Maria Lang, Vem är jag? Dagmar Lange eller Maria Lang, Norstedts 1985, s. 234. 
Barbara ter sig i svart sorgdräkt, hur "nästan romantiskt vacker" farbrodern Tord är då han framför Appassionatan på flygel, och hur en bjudning med de misstänkta under mordutredningen formar sig till "den största naturliga och angenäma samvaro" (s. 60, 99, 101).

Det har diskuterats huruvida Puck kan uppfattas som "författarens norm" eller om texterna medger en mera distanserad hållning till berättaren. ${ }^{4}$ Först och främst är Puck i likhet med Trenters Friberg tillförlitlig både som rapportör och som moralisk karaktär och får därmed auktoritet i sina värderingar. Å andra sidan är hon begränsad i det detektiva skarpsinnet på det sätt som hör Watson-modellen till. Elgström och Runnquist citerar i sin Svensk mordbok en replik av Puck ur Farligt att förtära som vore den en sammanfattning av Maria Langs egen hållning: "För mord är kulmen av ett drama som bränns av när mänskliga lidelser och affekter drabbar samman. Och därför är det människorna man skall studera. Inte deras fingertoppar eller deras alibin eller något sådant, även om det också kan vara till en viss hjälp, utan deras känslor och reaktioner och tidigare upplevelser" (s. 120). ${ }^{5}$ Faktum är att även om lidelserna i den romanen som annars hos Lang onekligen står i centrum, löses mordgåtan just genom att Christer Wijk lyckas spräcka ett alibi. Puck kan heller inte i någon av de åtta romanerna uppdaga sanningen utan står ständigt lika förbluffad eller chockad då mördaren namnges.

Till saken hör också att Puck har begåvats med en läggning för svartsjuka som skall ge nerv åt det romantiska inslaget i texterna och som inte minst i Tragedi... orsakar komplikationer i hennes egenskap av berättare. Hon har uppenbart svårt att betrakta den vackra Barbara med opartiska ögon, försöker lansera henne som misstänkt och bekänner då också en "utpräglad aversion mot allt vad blondiner heter" (s. 127). Pucks känslosvall får i andra sammanhang nyanseras av maken Einars eller pappan Johannes mera skeptiska hållning (s. 22, 27, 125). I Se döden på dig väntar förälskar hon sig i en av de misstänkta och kommer i än högre grad att illustrera hur bristen på distans omöjliggör en klarsyn i brottshistorien.

50-talets svenska kriminalroman har i allmänhet beskrivits som ett relativt enhetligt fenomen, men inom ramen för dess beroende av den anglosaxiska pusseldeckaren rymmer den i själva verket en del spänningar. Man kan å ena sidan se ett närmande till svensk verklighet och en strävan till realism som spränger pusseldeckarens snäva sociala horisont både i H.-K. Rönnbloms landsortsmiljöer och i Vic Sunesons bilder av polisens rutinarbete. Samtidigt omger Rönnblom sin detektiv Paul Kennet med påfallande ironier gentemot genremönstret och en roman som Sunesons Är jag mördaren?, 1953, framhäver likaledes en ironisk medvetenhet om genrenormerna med hjälp av diverse experimenterande grepp. Texternas fiktiva karaktär poängteras, kriminalromanen som spel med läsaren snarare än som verklighetsillusion ställs i centrum. Hos Lang finns liknande drag i Inte flera mord med dess uttalade anknytning till komedistycket Arsenik och gamla spetsar, och framförallt i debutromanen Mördaren ljuger inte ensam, där texten får en emellanåt uppsluppen ton genom att påminna om genrens schabloner. I Mörkögda augustinatt verkar däremot Lang

4 Sara Kärrholm, Konsten att lägga pussel. Deckaren och besvärjandet av ondskan i folkhemmet, Symposion 2005, s. 183; Maria Söderlund, ”För het på gröten? Maria Lang och sexualiteten”, i Jury 1997:4.

5 Jörgen Elgström och Åke Runnquist, Svensk mordbok, Bokvännerna 1957, s. 132. 
vilja förstärka illusionen i sin egen berättelse genom att ställa den mot de uppenbara överdrifterna i den hårdkokta Mickey Spillane-deckare som Pucks barnflicka läser. Tragedi... visar prov på en snarlik teknik. Lottas entusiasm inför den spännande mordgåtan får understryka barnsligheten i ett sinne som hämtat lärdomar ur mer eller mindre olämplig litteratur och därför heller inte kan förstå dödens mörka realitet. All form av parodi eller ironisk självbespegling saknas här.

Två verk ur traditionen anmäler sig som aktuella intertexter till Langs roman. Den låter sig jämföras med Dorothy L. Sayers’ De nio målarna ( The Nine Tailors, 1934), vilken till stora delar utspelas under en nyårshelg och kring en landsortskyrka och dess prästgård. Liksom Lang låter Puck Bure vittna om sin respekt för den kyrkliga traditionen, genomsyras Sayers' roman av kärlek till den kultur som den anglikanska kyrkan representerar. Vad gäller intrigmönstret ligger Tragedi... dock närmare Agatha Christies Mordet i prästgården (Murder at the Vicarage, 1930), som kom i svensk översättning så sent som 1951. Även här finns den rumsliga avgränsningen till en liten landsortsby vars invånare ganska snart blir de enda tänkbara misstänkta och där just prästgården fungerar som ett centrum i skeendet. Här finns dessutom villospår som på ett bestickande sätt påminner om varandra - hos Christie en silvertjuv som utger sig för att vara arkeolog, hos Lang en stöld av kyrksilvret, som emellertid i sista hand visar sig vara en av Mårten Gustafssons provokativa skämtsamheter. Lottas roll motsvaras hos Christie av kyrkoherdens unge brorson, som är lika opassande munter inför det mysteriösa mordet. Men jämförelsen med Christie får samtidigt skillnaderna de två emellan att framträda. Lang använder sig inte bara av de "gotiska" eller skräckladdade inslag som föranlett K.Arne Blom att jämföra henne med Mary Roberts Rinehart. Hon saknar dessutom det lättsamma tonläget hos Christie och tycks istället utnyttja genren för att belysa ett angeläget ärende i samtiden, den ensamstående kvinnans situation sådan som den kommer till synes via Hjördis Holm.

Hjördis är samtidigt ett av flera kvinnoöden från marginalen som via brottshistorierna träder fram i Langs romaner. Viveca Stensson i Mördaren ljuger inte ensam kan först med bekännelsen om mordet också öppet vidgå sin homosexuella läggning. Marja i Farligt att förtära får berätta om sin fattiga mor, som utnyttjades av en samvetslös förförare och drevs till självmord. Jan Hede i En skugga blott ger en inblick i den kärlekslängtan som präglat hans offer, den oansenliga Eva Clason - på många sätt en yngre upplaga av Hjördis Holm.

Dorothy L. Sayers hävdar i en essä att pusseldeckaren per definition aldrig kan nå litteraturens högsta nivåer:

Though it deals with the most desperate effects of rage, jealousy and revenge, it rarely touches the heights and depths of human passion. It presents us only with the fait accompli, and looks upon death and mutilation with a dispassionate eye. (---) A too violent emotion flung into the glittering mechanism of the detective story jars the movement by disturbing its delicate balance. The most successful writers are those who contrive to keep the story running from beginning to end upon the same emotional level, and it is better to err in the direction of too little feeling than too much. ${ }^{6}$

6 Dorothy L. Sayers, "The Omnibus of Crime”, i Detective Fiction. A Collection of Critical Essays, red. Robin W. Winks, Prentice-Hall Inc. 1980, s. 77. 
Till Maria Langs författarkaraktär hör både dessa starka känslor och avsaknaden av den "fina balans" Sayers talar om och det beror bara delvis på patetiken hos berättaren Puck Bure. Det finns hos Lang en strävan att beröra läsaren på ett sätt som uppfattats som främmande för pusseldeckaren. Kännetecknande är att hon använder den anspråksfulla, höglitterära beteckningen "tragedi" på sin roman. Titeln bör då inte tolkas enbart som en anspelning på Thomas Grays "Elegy On A Country Church Yard", utan Lang återkommer gärna till de "tragiska" aspekterna av den brottshistoria som avslöjas, här och i andra av hennes romaner, och som då också kommer att omfatta förövaren (s. 29, 45, 70, 137, 150). Medan slutavsnittet i Christies Mordet i prästgården kan läsas som försvar för det dödsstraff som väntar de skyldiga, framstår Hjördis Holm och flera andra av Langs mördare framförallt som offer för usla omständigheter. I en genre där brottslingen i allmänhet förkroppsligat Ondskan i dess mest oproblematiska gestalt porträtterar Lang ofta sina gärningsmän med vilja till förståelse och nyansering, något som dessutom får konsekvenser för romanernas komposition. Pusseldeckaren av Christies eller John Dickson Carrs slag siktar fram emot den stora scen då detektiven avslöjar mördaren och hur denne burit sig åt. Langs romaner siktar däremot mot det ögonblick då brottslingen själv får ta till orda och sätta in sin handling i ett sammanhang, göra den begriplig mot bakgrund av en livshistoria. Vi möter hos Lang hela biografier, ofta av omfattningen 8-10 sidor, och presenterade med uppenbar avsikt att förklara och vinna förståelse. Mot den triumferande berättelsen om brottets uppklarande spänner en annan och dystrare berättelse om hur en människa förvandlas till mördare. ${ }^{7}$

Langs mördare begår, med ett undantag, inte sina brott för materiell vinnings skull. De handlar i affekt, i rädsla eller utifrån motiv som måste uppfattas som patologiska. Så gott som genomgående är det människor som blivit känslomässigt utarmade, skadade eller kränkta. En långvarig psykisk belastning ger till sist utslag. Viveca, en lesbisk kvinna som alltid fått dölja sin läggning för omgivningen, mördar därför att "behärskningen" under några sekunder sviker henne (Mördaren ljuger inte ensam, s. 212). Margit Holt upplever en "vånda" som får det att svartna för ögonen. Här finns roten till det onda ända tillbaka till 20-talet, då föräldrars oförståelse lagt grunden till ett olyckligt äktenskap (Inte flera mord, s. 192, 199). Pucks gode vän Jan Hede grips av ett "primitivt" raseri och dödar den unga kvinna som lånat honom pengar och hotar förstöra hans nya kärlekslycka (En skugga blott, s. 245). Otto Malmer som på 30-talet straffats med ridpiska av fadern för en kärleksaffär tappar "besinningen" efter en vecka av sömnlöshet och grubbel och mördar den kvinna som bär deras gemensamma barn. Han har därefter blivit oförmögen all sexuell lycka. Tjugo år senare mördar han även sin far (Rosor, kyssar och döden, s. 204). Paul Sandvall slår i "'besinningslös vrede och svartsjuka" sönder ansiktet på sin älskade då han upptäcker hennes svekfullhet (Se döden på dig väntar, s. 229). "(J)ag har aldrig kunnat tåla att nån har slagit mig", säger Hjördis Holm då hon berättar om Arne Sandells död: "(N)är jag tog emot mig

7 Agatha Christie använder visserligen titeln "tragedi” i sin Three-Act Tragedy, 1934 (Tragedi i tre akter), men utan att avvika från sin gängse, lätt ironiska ton. Det skall också noteras att Maria Lang i sin självbiografi tar avstånd från varje ambition att förvandla deckaren till en tragedi eller att vara "verklighetstrogen". Hennes deklarationer ter sig emellertid som ett försvar för pusseldeckaren generellt och mot Raymond Chandlers s.k. "våldsdeckare" snarare än som ett försök att beskriva den egna produktionen. Se Lang, Vem är jag? s. 183f. 
med handen fick jag fatt i en yxa. Och sen... ja, sen vet jag inte längre vad det var som hände" (Tragedi... s. 158). Avviker från mönstret gör den unga Marja Kroog som mördar andra flickor för att de skall slippa "ligga med motbjudande karlar mer". Bakgrunden är här det kärlekssvek modern blivit utsatt för och hennes efterföljande självmord (Farligt att förtära, s. 245). Torvald Björne till sist dödar däremot i pusseldeckarnas traditionella ordning, kallt beräknande och med sin penninglystnad som drivkraft (Mörkögda augustinatt, s. 233).

Karaktäristiskt nog är Björne, den mest schablonmässige av Langs förövare, också den som får minst utrymme att förklara sitt handlande. Han har i likhet med så många andra av pusseldeckarnas brottslingar fallit för de frestelser det moderna samhället erbjuder och hans usla moral blir fullt tydliggjord då han förskingrat för en barnkoloniförening. Hjördis Holm kan snarare ses som ett utnyttjat offer för liknande tendenser, då hennes pengar fått finansiera paret Sandells slösaktiga leverne.

Langs betoning av sexualitetens betydelse för mänskligt handlande har uppmärksammats allt sedan debuten. Våldet sammanhänger oftast på ett eller annat sätt med den emotionella sårbarhet som har sin grund i sexualiteten. Sara Kärrholm betecknar träffsäkert hennes romaner som en "populariserad freudiansk centrering av driftslivets mekanismer". ${ }^{8}$ Det freudianska mönstret ges emellertid inte samma vikt i Tragedi... som i flera av de andra romanerna. Hjördis får själv tona ner vidden av den frustration hon upplevt inför Arnes kärlekssvek. Detta till trots har även hennes "tragedi" sitt ursprung i det privata förflutna, där familj och sexualitet generellt utgör de stora, freudianskt signerade konflikthärdarna. Lang är i detta avseende typisk för samtida tendenser i genren.

Den amerikanske författaren S.S. Van Dine hade i de tjugo punkter han 1928 formulerade som ett regelverk för deckarförfattare bl.a. hävdat att psykologiska analyser var överflödiga inom genren. ${ }^{9}$ Van Dines hållning kan ses som ett visserligen extremt men karaktäristiskt uttryck för pusseldeckarnas ointresse för mördares motiv. Genren fick närmast en matematisk-logisk karaktär med fokus främst på frågorna om vem som haft tillfälle till brottet och hur detta begåtts. Först i efterkrigstidens kriminallitteratur kan ett genuint intresse för psykologi spåras. Sally R. Munt ser förändringen som genomdriven framförallt av kvinnliga utövare och framhåller bl.a. Charlotte Armstrong och Patricia Highsmith. ${ }^{10}$ Man skulle kunna komplettera med sådana manliga konkurrenter som Ira Levin och William March, men framförallt är det svårt att bortse från en växelverkan mellan film och skönlitteratur och från de regissörer - Alfred Hitchcock, Otto Preminger, Robert Siodmak - som från och med krigsslutet excellerade i psykoanalytiskt inspirerade studier i brott. ${ }^{11}$ Ofta handlar det i såväl skönlitteraturen som filmkonsten om den form av thriller där det avvikande och skrämmande i gärningsmannens psyke står i fokus. För bilden av vardagsmänniskans kriminalitet framstår däremot Georges Simenon som en föregångare. I Maria Langs romaner beskrivs

8 Kärrholm, Konsten att lägga pussel, s. 149.

9 Van Dines punkter sammanfattas och diskuteras i Tzvetan Todorov, "Kriminalromanens typologi”, i Brott, kärlek, äventyr. Texter om populärlitteratur, red. Dag Hedman, Studentlitteratur 1995, s. 189.

10 Sally R. Munt, Murder by the Book? Feminism and the Crime Novel, Routledge 1994, s. 15.

11 Till romanerna hör Levin, A Kiss before Dying, 1953 (Bädda för död), March, Bad Seed, 1954 (Det onda arvet), till filmerna Hitchcocks Spellbound, 1945 (Trollbunden), Premingers The Whirlpool, 1950, och Siodmaks The Spiral Staircase, 1946 (Spiraltrappan). 
ett par mördare som patologiska fall - det handlar om Farligt att förtära och Rosor, kyssar och döden - men vanligare är att förövaren i likhet med Viveca Stensson i Mördaren ljuger inte ensam uppfattas som "trivsam och mänsklig och normal" (s. 150). Så är fallet också i En skugga blott, i Se döden på dig väntar och i Tragedi....

Man kan i anslutning till Peter Brooks också se ett samband mellan detta tidstypiska intresse för Freud och den utpräglat melodramatiska karaktären på Langs texter. Psykoanalysen liksom melodramat förutsätter enligt Brooks "dualistiska" konflikter av starkaste slag.. Han skriver: "Psychoanalysis can be read as a systematic realization of the melodramatic aesthetic, applied to the structure and dynamics of the mind". ${ }^{12}$ Ifråga om Lang gäller också det motsatta, att närheten till freudianismen gynnar en estetisk teknik som framhäver känslornas och de inre konflikternas styrka. Överhuvudtaget tycks inte bara mördaren utan många av figurerna hos Lang permanent befinna sig på bristningsgränsen. Aggressioner och lidelser svämmar över som en följd av brottet. Langs dragning till melodramat exemplifieras kanske tydligast i Inte flera mord, där offrets syster kastar sig över den dödes lik på ett sätt som får Puck att associera till "de stora operasluten" och där en annan dam bidrar såväl med en teatermässig svimning som med ett anfall av hysterisk gråt under framförandet av en aria (Inte flera mord s. 27, 65, 97).

Också Tragedi... innehåller sin beskärda del av hysteri, med Puck och andra i huvudrollen, men är annars uppbyggd framförallt kring ett antal starkt spänningsladdade entréer i prästgårdssalongen, vilka på en gång tjänar som cliffhangers i kapitelsluten och understryker en dramaturgisk teknik. I en följd av interiörscener, emellanåt brutna av inslag främst från den dystra kyrkogården, fungerar mördarens bekännelse som kulmen på en rad av tidigare sensationella tillkännagivanden, beskyllningar och avslöjanden. Langs texter bär på en skräckblandad fascination inför det skandalösa, de situationer där den sociala konvenansen bryter samman och takt och ton går förlorade. Sådana känsloutbrott blir samtidigt inte opåtalade. Ofta ljuder hos Lang en disciplinerande stämma som påminner om normstyrkan i det samhälle där skeendet utspelas och som står fast gentemot brottets konvulsioner. Betecknande nog făr en av fadersgestalterna i Tragedi..., kyrkoherden Tord, vid ett sådant tillfälle återföra hjorden till ordningen "med samma kärva röst som han använde på predikstolen: -Jag tror inte att vi skall tillåta oss att tappa besinningen och bära oss illa åt, även om vi litet till mans är omskakade och ur gängorna" (s. 35).

\section{Idyllen}

Den svenska 50-talsdeckaren har gärna uppfattats som generellt idyllisk. Sara Kärrholm menar t.ex. att de dåtida pusseldeckarna "baserade sina intriger på en föreställning om Sverige som en skön och trygg idyll". ${ }^{13}$ Lars Wendelius talar om en "tendens till idyllisering och harmonisering" i 40- och 50-talets detektivromaner och ställer dessa mot de "apokalyptiska

12 Peter Brooks, The Melodramatic Imagination. Balzac, Henry James, Melodrama and the Mode of Excess, Yale University Press 1995, s. 201, 17ff. Exempelvis tvingar kraften och dynamiken i en bakomliggande förträngning fram det överdrivna utspel i hysterin som direkt påminner om melodramat.

13 Sara Kärrholm, "Pusseldeckaren och folkhemmets bortträngda mörker”, i Hotad idyll, Berättelser om svenskt folkhem och kallt krig, red. Salomon, Larsson, Arvidsson, Nordic Academic Press 2004, s. 81. 
tonfall" man kan möta hos Henning Mankell. ${ }^{14}$ Sannolikt bidrar just kontrasten gentemot senare tiders svenska deckare, alltifrån Sjöwall \& Wahlöös debut med Roseanna, 1964, till att förstärka bilden av föregångarna. 50-talets s.k. "fyra stora", Stieg Trenter, H.-K. Rönnblom, Vic Suneson och Maria Lang, kan jämförelsevis framstå som i än högre grad ointresserade både av den vardagliga kriminalitet som senare blivit ett självklart inslag i den moderna polisromanen och av samhällsproblem överhuvudtaget. Att förknippa dessa författare med idyllen ter sig inte desto mindre direkt missvisande i tre fall av fyra.

'Idyller är till för att misstros", poängteras i H.-K. Rönnbloms Bok över obefintliga, visserligen utgiven så sent som 1962 men ytterst representativ för författarskapet i dess helhet. ${ }^{15}$ De flesta av Rönnbloms romaner tar plats just i de små samhällena och utmärks av en illusionslöst genomskådande hållning gentemot den konformism som är trygghetens baksida. Hos Vic Suneson är det ett återkommande grepp att redan inledningsvis framhäva de förgiftade och hatiska relationerna romanfigurerna emellan. De avskilda miljöer i havsband eller fjällvärld, som han ibland utnyttjar för sina mordhistorier, bär heller inget av idyllens prägel. Stieg Trenter kan vid enstaka tillfälle, i Aldrig näcken, 1953, använda sig av skärgården och dess anknytning till svensk sommaridyll som en spelplats för brottet. Men vanligtvis föredrar Trenter även på 50-talet Stockholms hektiska atmosfär eller de internationella arenor där huvudpersonen Harry Friberg nu får framträda i en mera extravagant äventyrar- och detektivroll än i de tidigare berättelserna.

Återstår Maria Lang, som däremot placerar roman efter roman i miljöer vars idylliska karaktär markeras med all önskvärd tydlighet. Typiskt är att ingen av hennes tre deckare som utspelar sig i Stockholm med omnejd kan sägas ge någon upplevelse av storstaden med dess tempo, dess brokiga liv och offentliga miljöer. En genomgång av hennes åtta första romaner låter oss istället möta sommarstugan på en ö i en vacker Bergslagssjö i Mördaren ljuger inte ensam; gymnasiet med dess vårbal i Farligt att förtära; Skoga, "en av de fridsammaste och till vila mest inbjudande småstäderna i Sverige", "vilken underbar liten idyll!" i Inte flera mord (s. 7, 11); humanistiska biblioteket, beläget vid Stureplan, men betecknande nog ändå omtalat som "pittoreskt och idylliskt" i En skugga blott (s. 39); herrgården med dess ljuvligt doftande rosor i Rosor, kyssar och döden; prästgården vid juletid i Tragedi...; ånyo sommarnöjet och nu även den äktsvenska kräftskivan i Mörkögda augustinatt. Mönstret varieras obetydligt i Se döden på dig väntar. Valet av Drottningholmsteatern som handlingens centrum lägger tonvikt snarast vid den traditionstyngda kultur Lang visar sin högaktning i flera av de andra romanerna och som då blir ett inslag i idyllen.

Jörgen Elgström och Åke Runnquist menar att den svenska kriminalromanen länge brottades med ett trovärdighetsproblem i så måtto att mellankrigstidens läsande publik hade svårt att acceptera mordhistorier på inhemsk grund. ${ }^{16}$ Med Trenters genombrott vid krigsslutet kan emellertid detta problem sägas ha förvandlats till en styrka, då just de suggestivt återgivna Stockholmsscenerierna gav romanerna åtskilligt av deras särprägel. Medan Trenter generellt

14 Lars Wendelius, Rationalitet och kaos. Nedslag i svensk kriminalfiktion efter 1965, Gidlunds 1999, s. 234.

15 H.-K. Rönnblom, Bok över obefintliga, Norstedts 1962, s. 28.

16 Elgström och Runnquist, Svensk mordbok, s.93. 
begagnar sig av autentiska och ibland mycket välkända storstadsmiljöer och tecknar dem med en strävan till exakthet, väljer Lang med några få undantag - Drottningholm, humanistiska biblioteket - att istället konstruera fiktiva miljöer, vars representativa drag accentueras. Betecknande nog sägs det om sommarhuset på "Ön" i Mördaren ljuger inte ensam att "det förkroppsligade drömmen om en sportstuga" (s. 13) och spelplatsen i Rosor, kyssar och döden betecknas som "Herrgården" med versal (s. 22). Det känsloladdade utspelet karaktärerna emellan träder $\mathrm{i}$ än högre grad i förgrunden i dessa stiliserade, ofta ganska tunt tecknade miljöer.

Väl att märka är miljöerna heller inte avsedda att bidra till gåtans komplikation på det sätt som sker redan hos Poe och därefter hos t.ex. Doyle, John Dickson Carr eller Trenter, författare som med förtjusning döljer ledtrådar till problemets lösning i sina noggranna brottsplatsbeskrivningar. De planskisser som Lang ibland infogade i sina texter bör också snarast uppfattas som eftergift till konventionen, något som redan framhävts av kritikerna. ${ }^{17}$ Det torde vara omöjligt att skingra mysteriet i någon Lang-roman genom ens det mest ambitiösa studium av dessa skisser.

Framförallt ger idyllerna möjlighet till starka effekter, då brottshistorien kombineras med en skådeplats som ter sig välbekant eller stabil och främmande för all form av kriminalitet. Langs teknik erinrar om den som återfinns i de anglosaxiska detektivromanerna alltifrån 1800-talet och fram till och med mellankrigstiden. W.H. Auden har i en essä talat om den engelska lantegendomen som "the Great Good Place", en version av Eden som i kriminalromanerna utsätts för en dramatisk störning genom det mord som inträffar - "the more Edenlike it is, the greater the contradiction of murder". ${ }^{18}$ Idyllens uppgift blir att ge relief åt brottet, att understryka dess gräslighet. Dennis Porter citerar Auden i sin The Pursuit of Crime. Art and Ideology in Detective Fiction och menar att brottet i engelska pusseldeckare mot denna bakgrund av ordning och harmoniska sociala relationer framstår som resultatet av den enskildes ondska, att det saknar social betydelse genom att bottna i sådana evigt mänskliga drag som svartsjuka eller girighet. ${ }^{19}$ Lang utnyttjar spänningen mellan idyll och våld på ett likartat sätt men utan det entydiga ideologiska innehåll Porter uppfattar. Brottet ses i ett komplexare sammanhang, idyllen får en mera ambivalent karaktär. I Tragedi... rymmer idyllen från första början fröet till sin egen undergång, men återupprättas ändå till sist, i skärande kontrast mot de mörka hemligheter som avslöjats via mördarens berättelse.

Lang söker vinna slagkraft ur sin inramning. I ett av "de största och trivsammaste rum" Puck Bure någonsin sett, prästgårdens s.k. salong, står en "högrest julgran" med "frisk och eggande doft" och där finns också hennes lilla kusin Lotta, med sin "smittsamma barnslighet" och sina förväntningar inför kvällen. Men redan i textens första meningar talas det om den "mulna decemberdagen" där allt är "grått och dött och beklämmande" och där "raden av gravar, kors och gravstenar" dominerar betraktarens blickfång (s. 7). T.o.m. Lotta, som annars förser berättelsen med välberäknade portioner av naiv charm, får i inledningen antyda

17 Elgström och Runnquist, Svensk mordbok, s. 132.

18 W.H. Auden, "The Guilty Vicarage”, i Detective Fiction, s. 19.

19 Dennis Porter, The Pursuit of Crime. Art and Ideology in Detective Fiction, Yale University Press 1981, s. 193. 
de kusligheter som följa skall, då hon betraktar en av julkrubbans visa män och upptäcker att huvudet är "på vippen att trilla av" (s. 9). Förebådanden och upplevelser av "undertryckt spänning i den till synes så idylliska atmosfären", som det står i en annan roman (Rosor, kyssar och döden, s. 24), hör till de återkommande inslagen i Langs repertoar.

Omkastningen i Tragedi... sker efter att farbrodern Tor "enkelt och allvarligt" läst julevangeliet och efter julklappsutdelningen: "Julaftonsidyllen var fullständig... Då ringde det på ytterdörren" (s. 15). In träder Barbara Sandell, som inte bara bär på onda tidender om makens försvinnande, utan därtill förkroppsligar mer eller mindre hotfull kvinnlig sexualitet. Pucks make Einar får en "uppsyn av ormtjusad maskulinitet" heter det med tydlig hänvisning till frestaren i Paradiset.

Det är värt att påminna om att också det traditionella melodramat gärna tar sin utgångspunkt i idyllen, det godas hemvist, som sedan utsätts för ondskans anslag. ${ }^{20}$ Just i Tragedi... finns en passage, där Langs melodramatiska kontrasteringsteknik exemplifieras närmast övertydligt. Då Puck så småningom bearbetar sina upprörande intryck av julaftonen och åsynen av mordoffret ser hon framför sig "lösryckta och förvridna bilder, som tycktes ännu grällare och hemskare mot det omgivande mörkret". Den "lantliga och idylliska butiken" ställs mot "en gapande och blodig spricka i ett mörklockigt människohuvud" (s. 26).

Idyllens underminering bör naturligtvis ses som ett inslag i författarens spänningsskapande strategier, en påminnelse om instabiliteten i tillvaron. Motivet återkommer i Rosor, kyssar och döden, där det efter upptäckten av brottet talas om "den nästan ironiskt idylliska och vackra sommartavlan med vitstammiga björkar, solglittrande vatten och blånande skogshöjder" (s. 85). Det varieras i Se döden på dig väntar, där mordet ger Drottningholmsteatern "en instängd doft av unkenhet och förgängelse" (s. 136). Den bristning som här inträffar i den vackra fasaden samspelar också med de återkommande sammanbrotten i relationerna spelets aktörer emellan. Erfarenheten visar dessutom, att den skyldige hos Lang ofta döljer sig bakom en till synes oklanderlig mask - som fallet är i bl.a. Tragedi....

Berättelsen om mordutredningen varvas fortsättningsvis med täta påminnelser om julhelgen och dess underförstådda fridsbudskap. Puck besöker julottan, där Tord talar "enkelt och kärvt om ljuset i det stora mörkret" (s. 29) och juldagsmiddagen avslutas framför "den hemtrevligt knastrande björkvedsbrasan" (s. 71). Själva kyrkrummet med dess "kyliga och fridfulla stillhet" lyfts fram som något djupt respektingivande - besökarna sänker sina röster och saktar sina häftiga rörelser - och då kyrksilvret upptäcks vara försvunnet talar Puck högspänt om "de heliga nattvardskärlen, vilka från släktled till släktled hade vårdats och vidrörts av fromma händer och läppar" (s. 66f). Traditionen och den nedärvda kulturen representerar en stabilitet, vars värde betonas också genom citat av en hel psalmvers av Wallin, genom Pucks explicita anspelning på Grays kyrkogårdsdikt, och genom musikstunder där såväl Beethoven som Schubert avnjutes.

Mot idyllen står den dragning till skräckromanens register, som är än tydligare i andra Lang-romaner, men som här kulminerar med scenen då Puck finner Barbara död liggande ovanpå den nybegravde makens kista. Framförallt växer hotet mot Lotta, som i sin oskuld

20 Brooks, The Melodramatic Imagination, s. 29. 
och lekfullhet förkroppsligar idyllen och placeras i alltmer farofyllda situationer. Hon är med vid båda de tillfällen då Puck upptäcker mordoffren, först Arne och senare även Barbara, och blir då föremål för berättarens moderliga omsorger. Efterhand blir också Lottas förmåga att avlyssna samtal och fungera som ett oönskat vittne allt tydligare, bl.a. vid turerna kring det försvunna kyrksilvret. Möjligheten att hon kan avslöja Hjördis Holm driver till sist mördaren att handla; i romanens final står Lotta högst uppe på en brant vindstrappa, inom räckhåll för en hand som sträcks ut för att ge henne "den dödande stöten" (s. 148)

Det är en scen som dramatiskt ställer ondskan mot renheten, men karaktäristiskt nog förbyts hotet mot det oskyldiga barnet på nästa sida i ett helt annat stämningsläge. Den gråtande Hjördis försöker förklara: "Jag... jag ville inte alls skada Lotta. Jag var bara så rädd...". Mot genrens spänningskrav står Langs strävan att avdemonisera brottslingen. Men lika karaktäristiskt är också att romanen avslutas med att Lotta återfår sin tillfälligtvis försvunna kattunge, direkt ur handen på kriminalkommissarien Christer Wijk och med "en rad vänligt grinande kriminalmän" i bakgrunden (s. 160). Idyllen återställs genom ordningsmaktens försorg, tragiken i Hjördis Holms och de två mordoffrens historia förskjuts i bakgrunden.

\section{Kvinnliga positioner}

Romanernas kvinnliga perspektiv röjer sig framförallt via berättaren Puck, vars jalousie gärna stimuleras av presumtiva rivaler eller oförklarliga intermezzon. I Mördaren ljuger inte ensam försvinner den goda stämningen då skönheten Lil Arosander gör en "effektfull" entré: "Hur var det möjligt att en enda människa på detta sätt kunde sprida otrivsel och irritation bland oss allesammans?", frågar sig Puck och iakttar Einars nervösa beteende (s. 26). Än mera dramatiskt sker omkastningen i En skugga blott. Puck återvänder efter en utlandsresa, fylld av en längtan till hemmets härd som illustreras via ett Heidenstam-citat, men finner Einar utflugen ur bostaden, kvinnokläder slarvigt utslängda i deras sovrum och som kulmen ett naket kvinnolik i badkaret.

Från det ögonblick Barbara dyker upp i Tragedi... kommer också kriminalgåtan att sammanflätas med en berättelse om kvinnliga positioner och kvinnlig rivalitet. I Maria Langs kriminalromaner framträder ett förhållande även till en annan genre, den romantiska populärlitteratur som vänt sig så gott som uteslutande till kvinnliga läsare. Barbara är då hon inträder i handlingen iförd röd ulster och en blank ljusgrön sidenklänning som enligt Puck är "både för utmanande och för opraktisk för att passa ihop med ett intimt julaftonsfirande i hemmets lugna vrå" (s. 18). Barbaras framtoning av stilriktig femme fatale kommer visserligen att nyanseras något under romanens gång, men hon förblir i Pucks ögon en representant för "primitiv kvinnlighet" som drar till sig all manlig uppmärksamhet, "en häxa, en trollpacka från det tjugonde århundrandet" (s. 23, 81, 123).

I romanen uppträder Barbara Sandell som en hotande eller övermäktig konkurrent till inte mindre än fyra andra kvinnor. I förhållande till Tekla Motander finns redan i det förflutna en kamp om Teklas make Gerhard. Dottern Susann Motander strävar i sin tur att bli sedd av Mårten Gustafsson som emellertid tycks ha ögon enbart för Barbara. Det blir också tydligt av Pucks reaktioner att hon uppfattar en konkurrens om Einar. Men framförallt har Barbara 
redan besegrat Hjördis i tävlan om Arne och framstår nu som överlägsen också i en eventuell kamp om kyrkoherden Tord, som så småningom erkänner sig förälskad i den nyblivna änkan.

Tragedi... utnyttjar schabloner från och förväntningar skapade inom populärromantiken genom att ställa en god och självuppoffrande kvinna, Hjördis, mot en egocentrisk och sinnlig, Barbara. ${ }^{21}$ Männen ägnade "hela sin syn och hörsel och artighet och spiritualitet åt den blonda och sorgklädda Barbara Sandell", anmärker Puck. "Och ändå var det Hjördis Holm som oavbrutet sörjde för vår trevnad" (s. 81). Det finns i diskussionen kring pusseldeckaren närmast ett samförstånd om att genren med förkärlek använder sig av såväl mördare som mordoffer som läsaren får föga sympati för. Ett emotionellt engagemang i någon av dessa karaktärer skulle störa det intellektuella arbetet, alternativt den dominerande komeditonen.22 Man kan vad gäller Tragedi...och en del andra kriminalromaner skärpa iakttagelsen och snarare tala om att de tillgodoser ett önsketänkande av mordisk art. Barbaras död framstår i sammanhanget som straffet för hennes självupptagenhet, ett stycke didaktik format av en konventionell kvinnosyn och ägnat att tillfredsställa de läsare som via Puck känt en stigande aversion. $^{23}$

Hjördis Holms öde innebär samtidigt ett tydligt brott mot normerna. En del av slagkraften med Langs roman ligger i att Hjördis till skillnad från klichén aldrig får den belöning för sin omvårdande huslighet som mönstret tycks utlova. Askungen vinner inte sin prins utan pekas istället ut som mördare. Läsaren har annars all anledning att hysa välvilja mot Hjördis Holm, en blygsam och flärdfri människa som tvingats leva ett trist och enformigt liv, därtill en "absolut perfekt" husföreståndarinna (s. 8), uppskattad av prästdottern Lotta. Hjördis tycker sig förvisso ha rätten på sin sida, då hon kräver sina pengar tillbaka, men hon griper efter yxan först då hon blir slagen av Arne.

Finns här en sens moral? Hjördis dödande hugg mot Arne Sandell kan uppfattas som den yttersta reaktionen på ett patriarkalt förtryck. Underförstått upprepar Arne vad Hjördis tidigare blivit utsatt för av fadern, snål och girig om än inte fysiskt brutal. Men dråpet låter sig också tolkas utifrån ett mera traditionellt perspektiv. Hjördis livsöde är konsekvensen av att hon inte kan locka till sig någon form av manlig uppmärksamhet. I Langs värld får kvinnor sitt värde via männen. Det gäller Puck i förhållande till Christer Wijk och det gäller romanernas återkommande unga flickor, som är på väg att kvävas under sina auktoritära mödrar. Tekla Motanders dotter Susann i Tragedi... är ett exempel. Ett berömmande ord från Mårten Gustafsson "förvandlade" med ens flickan och "kom henne att bli både söt och tilldragande" iakttar Puck. Metamorfosen antyder det Askunge-mönster som aldrig förverkligas ifråga om

21 Lisbeth Larsson beskriver detta återkommande mönster i populärromantiken. Se Larsson, En annan historia. Om kvinnors läsning och svensk veckopress, Symposion 1989, s. $245 \mathrm{ff}$.

22 John Cawelti, Adventure, Mystery and Romance. Formula Stories as Art and Popular Culture, Chicago University Press 1976, s. 90ff ; George Grella, "The Formal Detective Novel”, i Detective Fiction, s. 84ff.

23 Raymond Williams talar om "magical solutions" som undanröjer en komplikation eller en spelets onda aktör. Se Williams, The Long Revolution, Broadview press 2001, s. 82f. Den självupptagna kvinnans död är ett återkommande motiv också i de romantiktexter Lisbeth Larsson har undersökt. Se Larsson En annan historia, s. 250. 
Hjördis (s. 142). Detsamma gäller den "bleka och tysta" Agneta Holt i Inte flera mord (s. 5) och Vivi Ann Renman i Mörkögda augustinatt. Maktsituationen könen emellan och Langs ambivalenta hållning illustreras också redan i inledningen av Tragedi..., då Puck - närmast i barnets tysta position gentemot de vuxna - avlyssnar ett samtal mellan hennes far professorn och farbrodern kyrkoherden. Dessa två herrar, vars auktoritativa status aldrig ifrågasätts i romanen, diskuterar då äktenskapet som ett alltigenom praktiskt arrangemang, ägnat att underlätta situationen för änkemannen Tord (s. 7f).

Självständiga kvinnor tillmäts heller inte stora möjligheter hos Lang. Mördarna i hennes två första romaner är båda sådana som skapat sig en egen karriär, Viveca Stensson som licentiat i litteraturhistoria, Marja Kroog som teaterregissör, men på olika sätt faller de offer för sexualitetens komplikationer. Tove Monrad, hovsångerska i Se döden på dig väntar, har valt att göra abort och beskrivs som präglad av "egoism och karriärhunger" (s. 214). Undantaget är författarinnan Elisabeth Mattsson i Inte flera mord, med Einars ord "en av de bästa och finaste människor jag har haft nåden att få lära känna”. Hon är ogift och har lämnat bort en son, men tillmäts ändå förmågan till ett positivt liv, möjligen därför att hon som producent av årligen utkommande kärleksromaner ständigt underhåller en romantisk föreställningsvärld av traditionellt slag. Texten ifrågasätter visserligen värdet i Mattsons litteratur, men Puck får konstatera "hur mycket hon ändå hade betytt för att forma min smak" (s. 75f).

Puck Bure själv har en modern och positiv syn på sexualiteten och visar sig oftast förstående och tolerant gentemot de olycksöden hon möter, men framstår samtidigt som mycket traditionell, fallen för hysteriattacker och svimningar på ett sätt som kan erinra om Richardsons 1700-talshjältinna Pamela. I detektivarbetet ter hon sig blott alltför välanpassad till en nedärvd genusordning, belåten med att tilltalas med "kära barn" av Christer Wijk och bidra med "kvinnlig intuition" till hans beundrade intellekt. ${ }^{24}$ Den avhandling hon arbetar på redan i den första romanen har heller inte fullbordats då Lang lämnar henne i Mörkögda augustinatt och där Puck istället verkar fullt upptagen av sina modersplikter.

\section{Ideologin}

"En kvinnohand, omsluten av en vit spetsmanschett" är vad Puck kan urskilja då ljusskenet i vindstrappan faller över den hand som "sträckts ut för att ge Lotta den dödande stöten" (s. 148). Texten har genomgående poängterat perfektionen hos Hjördis Holm, som inte med en min förråder att det är besvärligt med gäster och som ger sig tid att sätta nya och fräscha spetsar på sin klänning (s. 88). I efterhand undrar Puck: "...var det hela, när allt kom omkring en smula för perfekt? Hade det varit en attityd, som hon klamrat sig fast vid för att hindra sig själv att grubbla över det fasansfulla, som hade skett, och som inte kunde göras ogjort?" (s. 158).

24 I Se döden på dig väntar lyckas Puck svimma inte mindre än tre gånger. Redan i Farligt att förtära får Wijk uttala sin tacksamhet över Pucks insatser: ”Jag behöver minsann all hjälp jag kan få, och när det gäller att bedöma människor - både skurkar och andra - brukar kvinnans intuition inte vara att förakta...” (s. 127). För exempel på Wijks tilltal, se Farligt att förtära, s. 216, Inte flera mord, s. 127, En skugga blott, s. 23. 
Samtidigt som texten låter mördaren ge sin bild av skeendet och få tillfälle att vinna läsarens sympati dröjer den vid problemet att den till synes mest otadliga fasad ändå kan rymma en skyldig. Langs romaner präglas genomgående av denna dubbelhet: skräcken inför vad som döljs bakom det sociala rollspelet, strävan att förstå vad som bringat människor ur balans. Man kan samtidigt se hur texterna söker täcka över dilemmat genom en uppsättning manövrer som alla framhäver den samhälleliga gemenskap som ändå står till buds: mördaren finner åhörare redo att lyssna till hans omsorgsfulla förklaring; varje antydan om oförsonliga sociala konflikter avvisas; samförståndet mellan medborgare och myndighet framstår som totalt. Ansträngningen att lyfta fram en enighet kring normer och attityder som även mördarna omfattar blir påfallande i Langs texter. Tydligare än någon av sina samtida svenska rivaler inom kriminalromanen exemplifierar hon den strävan till bekräftelse av den rådande ideologin, som man sett som kännetecknande för genren. ${ }^{25}$

Det blev mer och mer tydligt att"det innebar en stor lättnad för den inbundna berätterskan att få öppet erkänna och avbörda sig den tunga hemligheten”, heter det i Tragedi...(s. 150). Likartade formuleringar återkommer i roman efter roman. 'Det är skönt att äntligen få tala ut" (Viveca i Mördaren ljuger inte ensam, s. 212), "det skall bli en lättnad att få tala om... alltsammans" (Jan Hede i En skugga blott, s. 241), "Det ...det skall snarast bli skönt att få tala om alltsammans" (Paul Sandvall i Se döden på dig väntar, s. 222). Brottslingen erkänner sin skuld och söker göra sitt handlingssätt begripligt för omgivningen. Bekännelsen tilldelas en tydlig terapeutisk funktion - det talas gärna om "bikt" då Langs karaktärer öppnar sig mot omgivningen - men den får också bevisa attraktionskraften i det samhälle som mördaren nu vänder sig till i hopp om att vinna förståelse. Att fyra av Langs åtta gärningsmän väljer att ta sitt eget liv ter sig i sammanhanget som en ytterligare bekräftelse på styrkan i det normsystem förövarna har brutit emot.

Undantaget är Viveca Stensson i Langs debutroman Mördaren ljuger inte ensam, som visserligen begår självmord, men avviker från Langs andra mördare genom att hon riktar en anklagelse mot samhället: "Min kärlek var stark och normal för mig, och att den ledde mig till svåra brott berodde inte på att den var särpräglad. Däremot har det kanske spelat en roll att samhället och min omgivning har varit sådana att jag har tvingats att leva ett i viss mån oärligt och osant liv" (s. 215). Fortsättningsvis kommer inte gärningsmännen att formulera någon sådan kritik. Den freudianska förklaringsmodell som dominerar i texterna tjänar istället till att privatisera varje konflikt. Fram träder en samhällsbild, som präglas av social harmoni i stort, men där de nära relationerna störs av övergrepp och kränkningar i det förflutna. Langs romaner fogar sig på så sätt till andra 50-talsversioner av Sverige som "folkhem" eller "lycklig demokrati", en nation som inte längre producerar konflikter samhällsgrupper emellan och som kan hantera sina individuella avvikare med tolerans.

En kriminalroman pekar ut mänskliga drivkrafter som avgörande för våldet och oskyldigförklarar andra. I Tragedi... kan Lang sägas utnyttja läsarnas sociala fördomar för att misstänkliggöra den auktoritära Tekla Motander, den supige och grove Connie Lundgren och

25 För en diskussion kring denna fråga, se min "Stieg Trenter - genren och samtiden”, i HumaNetten, vårnumret 2005, www.vxu.se/hum/publ/humanetten. 
kommunisten Mårten Gustafsson. ${ }^{26}$ I synnerhet gäller det Tekla, den av aktörerna som texten riktar starkast antipatier mot. Sedan åratal tillbaka har hon omgetts av ryktet att hon låtit sin make dö genom att medvetet försena hans transport till ett sjukhus. "Om det verkligen är sant", säger Einar, "då är det ett vidrigare mord än jag någonsin förut har kommit i beröring med" (s. 99). Till sist menar emellertid Christer Wijk att "kanske" var ändå Tekla oskyldig till makens död och istället ett offer för illvilliga rykten (s. 159).

Tekla Motander kan sägas vara omöjlig som förövare redan genom att hon misstänkliggjorts i sådan grad, men inriktningen på "tragik" och på förståelse för brottslingen ter sig också oförenlig med föreställningar om en ondska av det slag som antytts hos Tekla. Tragedi...är en av de Maria Lang-romaner som saknar karaktärer helt utan försonande drag. Typiskt nog beskrivs Arne, som ju hanterat Hjördis' förhoppningar på ett bedrägligt sätt, som "osedvanligt glad och lättsam och trevlig" (s. 21). Några av de som utnyttjat människor i det erotiska spelet står emellertid bortom den gemenskap som annars inrymmer så gott som alla figurer i Langs värld. De hör hemma i de två tidigaste romanerna: Marianne Wallman i Mördaren ljuger inte ensam - ett mord på henne var enligt Puck "både förståeligt och på något vis acceptabelt" (s. 99) - och Torkel Alm i Farligt att förtära - "en erotoman av ganska billigt och motbjudande slag" (s. 197).

Connie Lundgren, som förutom att vikariera som kyrkvaktmästare också är anställd i Sandells butik, sägs ha avundats Arne Sandell inköpet av lanthandeln som Lundgren själv varit spekulant på. Lundgrens syster vittnar emellertid om att "det var bäst som skedde, för Connie skulle aldrig i världen ha dugt till att sköta en stor handelsbod och handskas med anställda och kunder och räkenskapsböcker" (s. 75). Texten undanröjer all objektiv grund för något socialt agg från Lundgrens sida och han får också betona att mordet på hans chef gjort honom "så sorgsen som hade det varit bror min" (s. 76). I Langs romaner saknas överhuvudtaget inslag av det moderna samhällets konkurrens och gruppkonflikter. Närmast kommer rivaliteten två litteraturforskare emellan i En skugga blott, men de försonas karaktäristiskt nog i samband med de traditionella och respektingivande ritualerna vid en disputation.

Mårten Gustafsson, som till en början omtalas som vore han "en pestsmittad kriminaldåre" (s. 44), beskrivs i slutavsnitten av Puck som "trevlig" och som en ung man "vars radikala idéer mest syntes bestå i en pojkaktig lust att ställa till uppståndelse och chockera den sovande landsbygden omkring sig” (s. 145). Han har då gjort avbön för tilltaget att låna kyrksilvret och betygat sin aktning för kyrkoherden. Mårtens politiska uppfattning ses helt och hållet ur ett individualpsykologiskt perspektiv, som ett steg i hans mognadsprocess. Den radikalism som skulle kunna representera modernitetens hot mot traditionen visar sig till sist helt ofarlig. En annan ungdomlig outsider, mordoffret Tommy Holt i Inte flera mord, som beskyllts för incest med sin halvsyster, blir inte bara rentvådd från dessa anklagelser utan tilldelas även han en i grunden rejäl och tilltalande karaktär.

Mårten Gustafsson är också ett av få inslag i den svenska 50-talsdeckaren som berör kommunismen och som därigenom kan sägas anknyta till den pågående ideologiska kampen i det

26 Heta Pyrhönen diskuterar sådana narrativa strategier som en del i författarens spel med läsaren. Se Pyrhönen, Mayhem and Murder. Narrative and Moral Problems in the Detective Story, University of Toronto Press 1999, s. $166 f f$. 
kalla kriget. Här, lika litet som i någon annan roman av de ledande författarna - relevanta är Trenters Dockan till Samarkand, 1959, respektive Sunesons Och häcken växte, 1955, och Så spelar döden, 1956 - kommer emellertid de aktörer som betecknas som kommunister att få någon avgörande roll i skeendet. De förblir bífigurer, ibland som hos Trenter utsatta för ironi, ibland som hos Suneson istället behandlade med respekt för konsekvensen i en övertygelse, men aldrig framställda som en överhängande samhällsfara.

Framförallt Sara Kärrholm har hävdat ett samband mellan 50-talets svenska kriminallitteratur och "den övergripande kontexten av det kalla kriget" och menar att "(ä)ven den litteratur och film som inte hade ett explicit politiskt innehåll påverkades av det kalla krigets föreställningsvärld". ${ }^{27}$ För mig ter det sig istället slående att länkarna till den öst-västliga motsättningen är så utomordentligt svaga i dessa 50-talsromaner. Decenniets svenska deckare framstår snarare som ett uttryck för tendenserna att föra samtidens politiska diskussion inom ramen för föreställningar om en egen, svensk väg. De normbrott som ständigt står $i$ centrum i kriminallitteraturen relateras vad gäller svenska 50-talsdeckare aldrig till någon politisk ideologisk påverkan, utan behandlas istället som problem vars ursprung står att finna i alltigenom privata omständigheter - som hos Lang - eller i sådana moralkriser som sammanhänger med det moderna samhällets utveckling - som hos Trenter, Suneson eller Rönnblom.

Strävan att harmoniera slår igenom också i bilden av polisen. Lang skiljer sig på så sätt från en stor del av genretraditionen, där polismakten antingen förlöjligats till fördel för sådana privata utredare som Holmes och Poirot, eller utrustats med den temperamentsfulla excentricitet som utmärker bl.a. Vesper Johnson hos Trenter. Christer Wijk är däremot alltigenom tillmötesgående - "den hövligaste av alla poliskommissarier" (Farligt att förtära, s. 113) - och uttrycker gärna sin tacksamhet då de inblandade tycks hålla sig till sanningen. Vid ett tillfälle övertalar han en av dessa att vederbörande nog ändå får "finna sig i att vara förhållandevis misstänkt" (Mörkögda augustinatt, s. 197). I Tragedi... kan Wijk trogen sin roll som svärmorsdröm och gentleman visserligen "kyligt" huta åt Connie Lundgren, som borde ha lärt sig att "man inte späckar sitt tal med svordomar i damers närvaro" (s. 57) och han får visa skärpa och myndighet i olika kritiska faser av utredningen, men han annonserar i övrigt genomgående närhet snarare än distans till kretsen av misstänkta. Vid sin entré i romanen införs han "i triumf till det dignande kaffebordet" av makarna Puck och Einar (s. 35) och samtalar sedan "vänligt" och "tåligt" med de som nyligen fått kännedom om mordet på Arne Sandell. Scenen återkommer i flera andra romaner, där de inblandade är blott alltför villiga att låta sig granskas av polismakten. De som hävdar sin rätt till en fredad privatsfär även under en mordutredning framstår efterhand som naiva, alternativt otillständigt misstrogna gentemot överheten.

Familjen blir kärnan i den samhälleliga gemenskap Lang beskriver och därmed också i en ideologi som hävdar möjligheten av en social tillvaro utan konflikter. Christer Wijks nära och förtroliga relation till paret Bure gör att han snarast bör uppfattas som familjemedlem,

27 Kärrholm, Konsten att lägga pussel, s. 39, 26. 
som en i den stabila krets som Langs berättelser oftast tar sin utgångspunkt i och som sedan ger trygghet då våldet hotar. Ofta begränsas denna krets enbart till det äktenskapliga paret Puck och Einar tillsammans med vännen Wijk, ibland utökas den med fadern Johannes och här dessutom med farbrodern och den lilla kusinen. I Mörkögda augustinatt, den åttonde och sista romanen med Puck som berättare, tillkommer en liten dotter och en barnflicka.

Via kriminalberättelsen blir familjen föremål för ett mer eller mindre latent hot. Våldsamheterna som inträffar kan på ett indirekt plan uppfattas som attentat mot familjeharmonin, inte minst genom att våldet får slå till i Pucks omedelbara närhet. Greppet förstärker berättarens delaktighet i skeendet och har motsvarigheter redan i Stieg Trenters 40-talsromaner, men det făr hos Lang en särskilt laddad och ihärdig karaktär. Morden drabbar den närmaste vänkretsen (Mördaren ljuger inte ensam) eller den arbetsplats där Puck och Einar för tillfället är sysselsatta (Farligt att förtära). I ett fall finner Puck som redan nämnts ett lik i parets eget badkar (En skugga blott), i ett annat i trädgården till den villa där de vistas (Inte flera mord). I Rosor, kyssar och döden berörs den familj som Christer Wijk är på väg att gifta in sig i. En egen släkting blir ett av offren i Mörkögda augustinatt och i Se döden på dig väntar flätas mordhistorien samman med en romans, där Pucks äktenskap tycks i fara genom hennes förälskelse i en karismatisk dirigent. I ett par fall är mördarna nära vänner till Puck. I Tragedi... diskuteras vid flera tillfällen Hjördis Holm som en tänkbar andra hustru till änkemannen Tord, Pucks farbror. Romanerna undviker varje antydan om djupare motsättningar inom familjens ram - typiskt nog konfronteras aldrig Einar med Pucks relativt oskyldiga snedsprång med dirigenten - men exploaterar fruktan för den omvärld som kan störa tryggheten.

En jämförelse med Trenter är instruktiv och belyser hur två författare inom genren och i samma epok kan kretsa kring helt olika centra. Trenters hjälte Harry Friberg är ungkarl, har närmast försumbara kontakter med familj och släkt, och kan lätt uppfattas som representant för enskild, manlig initiativkraft i det nya efterkrigssamhället, en företagare ur medelklassen som möter omvärlden med optimism, om än med en viss ambivalens gentemot moderniteten. Hos Lang söker sig däremot Puck efter sina återkommande likfynd och andra erfarenheter av en bister verklighet ständigt tillbaka till det stöd och den tröst som familjen, i själva verket männen Einar, Johannes och Christer Wijk, kan ge henne. De föreställningar om tryggheten i den goda familjen som här träder fram står samtidigt i bjärtaste kontrast mot de brutalare insikter om familjelivet som romanerna också ger. Bilden av familjen som kärncellen i folkhemmet och förkroppsligandet av en vidare social gemenskap kan hos Lang aldrig helt förtränga de hatiska relationerna i de andra familjer som skärskådas i freudianismens avslöjande ljus. Här synliggörs både strävan till ideologisk förenkling och svårigheterna att täcka in alla de komplikationer som texterna rymmer.

\section{Analyserad litteratur:}

Mördaren ljuger inte ensam (1949), Vingförlaget 1952.

Farligt att förtära (1950), B. Wahlströms bokförlag 1960.

Inte flera mord (1951), Vingförlaget 1957.

En skugga blott (1952), B. Wahlströms bokförlag 1970.

Rosor, kyssar och döden (1953), Vingförlaget 1960. 
Tragedi på en lantkyrkogård (1954), Pan/Norstedts 1967.

Se döden på dig väntar, Norstedts 1955.

Mörkögda augustinatt (1956), Vingförlaget 1959.

Auden, W.H., "The Guilty Vicarage", i Detective Fiction. A Collection of Critical Essays, red. Robin W. Winks, Prentice-Hall Inc. 1980.

Blom, K. Arne, ”Appendix”, i Julian Symons, Lilla mordboken. Från detektivhistoria till kriminalroman, Berghs 1979.

Brooks, Peter, The Melodramatic Imagination. Balzac, Henry James, Melodrama and the

Mode of Excess, Yale University Press 1995.

Cawelti, John, Adventure, Mystery and Romance. Formula Stories as Art and Popular Culture, Chicago University Press 1976.

Carlsson, Ulf, "Stieg Trenter - genren och samtiden", i HumaNetten, vårnumret 2005, www.vxu. se/hum/publ/humanetten.

Christie, Agatha, Mordet i prästgården (Murder at the Vicarage, 1930), Bonniers 2000.

Christie, Agatha, Tragedi i tre akter (Three-Act Tragedy, 1934), Bonniers 1947.

Elgström, Jörgen och Runnquist, Åke, Svensk mordbok, Bokvännerna 1957.

Elgström, Jörgen, LaCour, Tage, Runnquist, Åke, Mord i biblioteket. Detektivromanens märkvärdiga historia, Bonniers 1961.

Grella, George, "The Formal Detective Novel", i Detective Fiction. A Collection of Critical Essays, red. Robin W. Winks, Prentice-Hall Inc. 1980.

Kärrholm, Sara, "Pusseldeckaren och folkhemmets bortträngda mörker", i Hotad idyll,

Berättelser om svenskt folkhem och kallt krig, red. Salomon, Larsson, Arvidsson, Nordic Academic Press 2004.

Kärrholm, Sara, Konsten att lägga pussel. Deckaren och besvärjandet av ondskan i folkhemmet, Symposion 2005.

Lang, Maria, Vem är jag? Dagmar Lange eller Maria Lang, Norstedts 1985.

Larsson, Lisbeth, En annan historia. Om kvinnors läsning och svensk veckopress, Symposion 1989.

Munt, Sally R., Murder by the Book? Feminism and the Crime Novel, Routledge 1994.

Porter, Dennis, The Pursuit of Crime. Art and Ideology in Detective Fiction, Yale University Press 1981.

Pyrhönen, Heta, Mayhem and Murder. Narrative and Moral Problems in the Detective Story, University of Toronto Press 1999.

Rönnblom, H.-K., Bok över obefintliga, Norstedts 1962.

Sayers, Dorothy L., "The Omnibus of Crime", i Detective Fiction. A Collection of Critical Essays, red. Robin W. Winks, Prentice-Hall Inc. 1980.

Sayers, Dorothy L. De nio målarna ( The Nine Tailors, 1934), Bonniers 1951.

Söderlund, Maria, "För het på gröten? Maria Lang och sexualiteten”, i Jury 1997:4.

Todorov, Tzvetan, "Kriminalromanens typologi”, i Brott, kärlek, äventyr. Texter om populärlitteratur, red. Dag Hedman, Studentlitteratur 1995.

Wendelius, Lars, Rationalitet och kaos. Nedslag i svensk kriminalfiktion efter 1965, Gidlunds 1999. Williams, Raymond, The Long Revolution, Broadview press, 2001. 